\title{
First Record of the Labrid Fish Cymolutes praetextatus from the Hawaiian Islands ${ }^{1}$
}

\author{
Fohn E. Randall, ${ }^{2}$ Ross C. Langston, ${ }^{3}$ and Mike Severns ${ }^{4}$
}

\begin{abstract}
The labrid fish Cymolutes praetextatus, previously known from East Africa to the Society Islands but not east of the Marshall Islands in the North Pacific, is reported from the Hawaiian Islands from two specimens collected in $18 \mathrm{~m}$ and an underwater photograph taken in $27 \mathrm{~m}$. One of the color descriptions by Jordan and Evermann in 1905 in their species account of C. lecluse indicates that they had a specimen of praetextatus.
\end{abstract}

The Xyrichtyinae, one of the subfamilies of the large fish family Labridae, contains five genera with species that can quickly bury themselves in sand (Randall and Earle 2004). This ability enables these fishes to live over open stretches of sandy bottom, a habitat denied other fishes that require the shelter of reefs or dense beds of algae or sea grass. One of the five genera is Cymolutes, erected by Günther (1861) for Fulis praetextata, a species described from Mauritius by Quoy and Gaimard (1834), and Xyrichthys microlepidotus Valenciennes in Cuvier and Valenciennes (1840), an unnecessary redescription of $X y$ richthys lecluse Quoy \& Gaimard (1824) from Hawai'i. Valenciennes also described Xyrichthys torquatus, giving the type locality as Surinam, now corrected to the East Indies. Following most recent authors, Bauchot (1963) treated praetextatus and torquatus as synonyms of Cymolutes lecluse, but she over-

${ }^{1}$ This research was funded, in part, by Grant No. NA04OAR4300143 from NOAA's Coral Reef Conservation Program and National Undersea Research Program, and the Hawai'i Undersea Research Laboratory. Contribution 2006-011 to the Hawai'i Biological Survey. Manuscript accepted 1 February 2006. Contribution 2006-011 to the Hawai'i Biological Survey. Manuscript accepted 1 February 2006.

${ }^{2}$ Bishop Museum, 1525 Bernice Street, Honolulu, Hawai'i 96817-2704.

${ }^{3}$ Department of Zoology, University of Hawai i, Honolulu, Hawaici 96822.

${ }^{4} 3415$ Kehala Drive, Kīhei, Maui, Hawai'i 96753.

Pacific Science (2006), vol. 60, no. 4:549-553

(C) 2006 by University of Hawai'i Press

All rights reserved looked the review of the genus by Schultz in Schultz and collaborators (1960), who clearly distinguished the three species.

The genus Cymolutes is easily separated from the other genera of the subfamily by having 72-93 scales in longitudinal series, compared with 26 for the other genera; no scales on the head; and 10 instead of 12 (rarely 11) branched caudal rays.

Cymolutes lecluse has long been recognized as endemic to the Hawaiian Islands. Cymolutes praetextatus and $C$. torquatus are both wide ranging from the east coast of Africa to French Polynesia; in the western Pacific from southern Japan to New South Wales and New Caledonia. Neither, however, is reported in the North Pacific east of the Marshall Islands.

\section{MATERIALS AND METHODS}

Specimens of Cymolutes are deposited in the Bishop Museum, Honolulu (врвм).

Methods of counting and measuring specimens of fishes follow Randall et al. (2002).

\section{RESULTS AND DISCUSSION}

R.C.L. observed an adult pair of a species of Cymolutes in May of 2005 while diving on a Halimeda bed in $18 \mathrm{~m}$ off West Maui that seemed different from $C$. lecluse in having numerous narrow orangish bars on the posterior half of the body. One was speared and identified as $C$. praetextatus, popularly known as the Knife Razorfish, the first record for the Hawaiian Islands. On a subsequent dive at the same locality, he collected a juvenile of this species. 
While examining the fishes identified as Cymolutes lecluse in the Bishop Museum, we discovered that one of three specimens of врвм 4701, obtained from a fish market in Honolulu before 1930, is C. praetextatus.

Jordan and Evermann (1905:328) reported 26 specimens of Cymolutes lecluse from the Hawaiian Islands, 4.8-6.25 inches (122-159 $\mathrm{mm}$ ) in length, one from Hilo and the rest from Honolulu. They gave a color description of one specimen that is consistent with the female of lecluse, mentioning "a small dark spot on upper posterior part of the caudal peduncle." They also provided a description of the life color of another specimen for which they cited the field number 03458 : "general color bluish white; edge of gillopening and posterior part of opercle pinkish yellow; a quadrate area from gill opening to vent and from ventral line of belly to level of lower border of eye pure white; an indistinct irregular band of pale pinkish yellow from below eye backward along upper border of quadrate white area; posterior half of side with about 13 transverse pale pinkish bars; a small round black spot, with bright greenish blue border on side above tip of pectoral and just below lateral line; anterior part of dorsal fin with a Y-shaped black line with greenish border; posterior part bordered with pale pinkish yellow." On reading this, we realized that they had a male specimen of C. praetextatus. Unfortunately, the specimen was not found at the National Museum of Natural History in Washington, D.C. (Jeffrey M. Clayton, pers. comm.).

M.S. provided the figure of Figure $1 A$ of a presumed male of Cymolutes praetextatus,

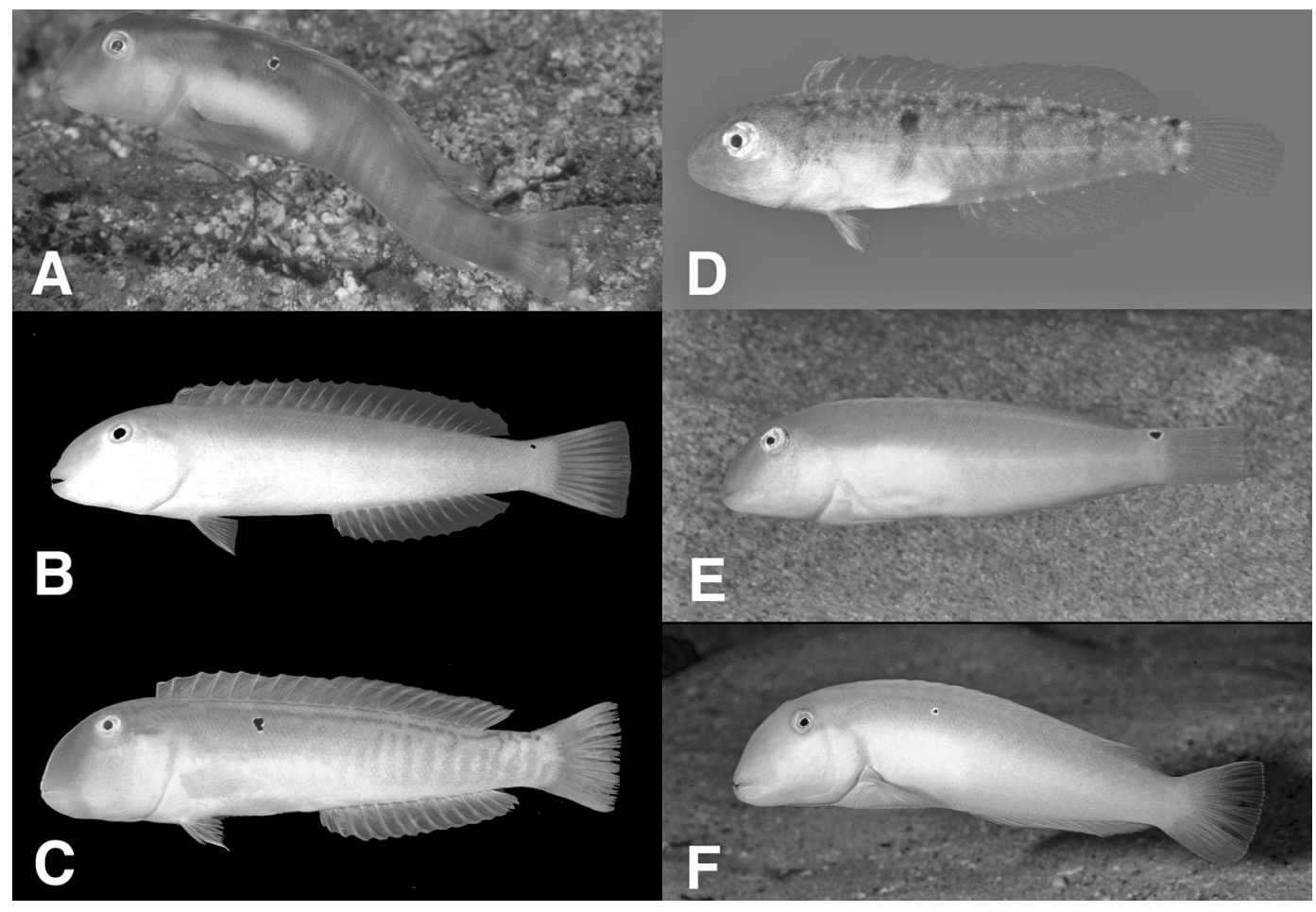

Figure 1. A. Cymolutes praetextatus, male, Makena, Maui, $27 \mathrm{~m}$ (M. Severns). B. Cymolutes praetextatus, врвм 27808, female, $64 \mathrm{~mm}$ SL, Enewetak Atoll, Marshall Islands, $3.5 \mathrm{~m}$ (J. Randall). C. Cymolutes praetextatus, врвм 32425, male, 130 mm SL, Sanur, Bali, 0.3 m (J. Randall). D. Cymolutes lecluse, врвм 37192, juvenile, 22 mm SL, Mākua, O'ahu, $15.5 \mathrm{~m}$ (J. Randall). E. Cymolutes lecluse, female, West Maui, $7 \mathrm{~m}$ (J. Randall). F. Cymolutes lecluse, male, Molokini, Maui, $20 \mathrm{~m}$ (J. Randall). 
photographed in $27 \mathrm{~m}$ off Mākena, Maui; the fish was not collected. We also include specimen photographs of non-Hawaiian female and male $C$. praetextatus as Figure $1 B$ and $C$, respectively. In addition, for comparison, an underwater photograph of a female of $C$. lecluse is provided as Figure $1 E$, and a male as Figure $1 F$. Figure $1 D$ is the first published illustration of a juvenile of $C$. lecluse.

Cymolutes praetextatus and $C$. lecluse share the same three small black markings: the black spot dorsoposteriorly on the caudal peduncle of the female, an ocellated black spot above the tip of the pectoral fin of the male, and a thin black line in the outer part of the first interspinous membrane of the dorsal fin of both sexes. The males and many of the females of praetextatus have a series of orange to pink bars in life on the posterior half of the body that are lacking in lecluse (except for one photograph of a 114-mm male of lecluse with faint posterior pale gray bars). The dark bars of praetextatus are often not visible on old preserved material. Therefore, the two species would be difficult to distinguish as preserved specimens were it not for the discovery by Schultz (1960) of the difference in the number of dorsal and anal soft rays. His table 95 compared the counts of these fin rays of Hawaiian specimens of $C$. lecluse with praetextatus from the Philippines, Marshall Islands, Tonga, and the Phoenix Islands. We have added our counts of 14 Bishop Museum specimens of lecluse and 20 of praetextatus to those of Schultz and present them as Table 1. It is noteworthy that none of the specimens of praetextatus has the combined count of 14 dorsal rays and 13 anal rays that are modal for lecluse.

TABLE 1

Dorsal and Anal Soft Rays of Species of Cymolutes

\begin{tabular}{|c|c|c|c|c|c|c|c|c|}
\hline & \multicolumn{4}{|c|}{ Dorsal Soft Rays } & \multicolumn{4}{|c|}{ Anal Soft Rays } \\
\hline & 12 & 13 & 14 & 15 & 11 & 12 & 13 & 14 \\
\hline $\begin{array}{l}\text { lecluse } \\
\text { praetextatus }\end{array}$ & 1 & 49 & $\begin{array}{r}32 \\
3\end{array}$ & 1 & 1 & 50 & $\begin{array}{r}32 \\
2\end{array}$ & 1 \\
\hline
\end{tabular}

The third species of the genus, Cymolutes torquatus (Valenciennes), is easily separated by having 12 dorsal soft rays, lacking the three small black markings, and having in adults a narrow dark bar posteriorly on the opercle, usually followed by a slightly oblique bar on the upper half of the body just behind the head.

Cymolutes praetextatus (Quoy \& Gaimard) Figure $1 A-C$

Fulis praetextata Quoy \& Gaimard, 1834:712, pl. 15, fig. 4 (type locality, Mauritius).

Novacula xyrichthyoides Bleeker, 1856:488 (type locality, East Indies).

DIAGNosis: Dorsal fin rays IX,12-14 (strongly modal 13), the first two spines flexible; anal fin rays II,11-13 (strongly modal 12); branched caudal fin rays 10 ; pectoral fin rays 12; lateral line interrupted, the pored scales 50-60+15-21; head scaleless; a pair of long, slender canine teeth at front of jaws, the lower pair fitting inside upper and overlapping lips when mouth closed; body depth 4.1-4.6 in standard length (SL); body compressed, the width 2.2-2.6 in body depth; dorsal profile of head steep and strongly convex; caudal fin truncate to slightly rounded; females pale gray to olivaceous dorsally, white to pale yellowish green ventrally, with a faint salmon pink to dull orange stripe along back above lateral line, often with narrow bars of the same color extending ventrally from stripe on posterior half of body; a small black spot dorsally on caudal peduncle just before base of caudal fin; a pale-edged black line distally on first membrane of dorsal fin; males generally darker and consistently with the posterior dark bars; small posterior black spot absent; a black spot bordered in pale blue above tip of pectoral fin, its upper edge touching lateral line; margin of dorsal and anal fins deep pink; upper and lower edges of caudal fin pink. Reported to $20 \mathrm{~cm}$ total length. Largest specimen examined, $130 \mathrm{~mm}$ SL.

REMARKS: In addition to documenting the presence of Cymolutes praetextatus in the Hawaiian Islands, we report here the first speci- 
men of the species from the Line Islands, врвм 37574, a mature female, $68 \mathrm{~mm} \mathrm{SL}$. It was collected by D. Ross Robertson at Kiritimati (formerly Christmas Island) in a channel north of Cook Islet in September 1998. This is not a surprising record because $C$. praetextatus has been reported from other South Pacific islands, including the Phoenix Islands to the southwest (first published by Schultz [1943] as C. lecluse) and the Society Islands to the southeast (first specimen, врвм 9094, also a mature female $68 \mathrm{~mm} \mathrm{SL}$, collected by J.E.R. in $3 \mathrm{~m}$ at Moorea in 1957).

Our only two records for the depth of Cymolutes praetextatus in the Hawaiian Islands are 18 and $27 \mathrm{~m}$. Most other records for the species are much shallower. Myers (1999:194) wrote of the habitat, "sandy areas of reef flats and shallow lagoons with scattered algae, rubble, or seagrasses to a depth of at least $6 \mathrm{~m}$." $\mathrm{He}$ added, "It is wary and not often noticed." Surprisingly shallow depths are recorded from Bishop Museum specimens. A 69-mm male specimen from Tutuila, American Samoa, was collected by Richard C. Wass in $0.5 \mathrm{~m}$. A $130-\mathrm{mm}$ male was taken by J.E.R. on the Bali reef flat in $0.3 \mathrm{~m}$, and a $73-\mathrm{mm}$ male from $1.5 \mathrm{~m}$ on the reef flat of North Male Atoll in the Maldive Islands. The following note about the species was added to the label for the last specimen: "When swimming over the bottom, pale with a yellowish longitudinal streak; when coming to rest, gets darker and banded, takes a sinuous shape, and is ready for a rapid dive into the sand (often next to a rock)."

Bishop Museum specimens of Cymolutes lecluse were collected from the depth range of $1-31 \mathrm{~m}$.

Because of the close similarity of Cymolutes lecluse to $C$. praetextatus, one might presume that the former arose from the latter in the isolation of the Hawaiian Islands, and that praetextatus recolonized the archipelago. The same scenario might also apply to the snake eel geminate pair Callechelys lutea and C. marmorata, and the damselfish pair Abudefduf $a b-$ dominalis and $A$. vaigiensis.

MATERIAL OF CYMOLUTES PRAETEXTATUS eXAmined: Tanzania, Mafia Island, врвм 17580, $50 \mathrm{~mm}$. Mauritius, врвм 16383, 45 mm. Maldive Islands, North Malé Atoll, врвм 18896, $73 \mathrm{~mm}$. Indonesia, Bali, врвм 32425, $130 \mathrm{~mm}$. Coral Sea, Kenn Reef, врвм 15047, $77 \mathrm{~mm}$. Mariana Islands, Guam, врвм 4703, 4: 50-104 mm. Marshall Islands, Majuro Atoll, врвм 9658, $79 \mathrm{~mm}$. Enewetak Atoll, врвм 7986, $83 \mathrm{~mm}$; врвм 27797, 2: 33-37 mm; врвм 27808, 5: 64-102 mm. American Samoa, Tutuila, врвм 28935, 69 mm. Line Islands, Kiritimati, врвм 37574, 68 mm. Society Islands, Moorea, врвм 9094, 68 mm. Hawaiian Islands, Maui, врвм 40167, $106 \mathrm{~mm}$; врвм 40386, $28 \mathrm{~mm}$. O'ahu, врвм $40209,153 \mathrm{~mm}$ (formerly misidentified as $C$. lecluse, one of three specimens of врвм 4701).

MATERIAL OF CYMOLUTES LECLUSE EXAMINED: Hawaiian Islands, Laysan, врвм 4702, $148 \mathrm{~mm}$. O'ahu, врвм 2074, $128 \mathrm{~mm}$; врвм 4701, 2: 131-139 mm; врвм 10156, $125 \mathrm{~mm}$; врвм 10640, $70 \mathrm{~mm}$; врвм 15399, $25 \mathrm{~mm}$; врвм 22739, 4: 30-36 mm; врвм 23529, 160 $\mathrm{mm}$; врвм 28146, $72 \mathrm{~mm}$; врвм $32821,2: 42-$ $57 \mathrm{~mm}$; врвм 37040, $93 \mathrm{~mm}$; врвм 37192, 2: 18-22 mm; врвм 40161, $49 \mathrm{~mm}$; врвм 40227, $114 \mathrm{~mm}$. Maui, врвм 40167, $106 \mathrm{~mm}$; врвм 40387, $30 \mathrm{~mm}$.

\section{Literature Cited}

Bauchot. M.-L. 1963. Catalogue critique des types de poissons du Muséum National d'Histoire Naturelle. Publ. Mus. Natl. Hist. Nat., no. 26:1-195.

Bleeker, P. 1856. Index specierum piscium malayo-moluccensium in voluminibus 110 Diarii Societatis Indo-Batavae desciptarum. Nat. Tijdschr. Neder-Indië 10:472500.

Cuvier, G., and A. Valenciennes, 1840. Histoire naturelle des poissons, vol. 14 . Chez Pitois-Levrault, Paris.

Günther, A. 1861. A preliminary synopsis of the labroid genera. Ann. Mag. Nat. Hist., ser. 3, 8:382-389.

Jordan, D. S., and B. W. Evermann. 1905. The aquatic resources of the Hawaiian Islands. Part I-the shore fishes. Bull. U.S. Fish Comm. 23 (1903).

Myers, R. F. 1999. Micronesian reef fishes. 3rd ed. Coral Graphics, Guam.

Quoy, J. R. C., and J. P. Gaimard. 1824. Pois- 
sons. Pages 192-401 in Voyage autour de Monde ... Exécuté sur les Corvettes de S.M. "L'Uranie" et "La Physicienne" pendant les Années 1817-20. Pille \& Aîne, Paris.

1834. Poissons. Pages 645-720 in Voyage de Découvertes de "l'Astrolabe," Exécuté par Ordre du Roi, pendent les Années 1826-29, sous le Commandement de M. J. Dumont d'Urville, vol. 3. J. Tastu, Paris.

Randall, J. E., and J. L. Earle. 2004. Novaculoides, a new genus for the Indo-Pacific labrid fish Novaculichthys macrolepidotus. Aqua 8 (1): 37-43.
Randall, J. E., J. L. Earle, and D. R. Robertson. 2002. Iniistius auropunctatus, a new razorfish (Perciformes: Labridae) from the Marquesas Islands. Cybium 26 (2): 93-98.

Schultz, L. P. 1943. Fishes of the Phoenix and Samoan Islands collected in 1939 during the expedition of the U.S.S. "Bushnell." U.S. Natl. Mus. Bull. 180.

Schultz, L. P., and Collaborators: W. M. Chapman, E. A. Lachner, and L. P. Woods. 1960. Fishes of the Marshall and Marianas Islands. Vol. 1. Families from Mullidae through Stromateidae. U.S. Natl. Mus. Bull. 202, vol. 2. 
